\title{
Analysis of Studies on COVID-19 Pandemic with Science Mapping Technique
}

\author{
İlknur Arslan Çilhoroz ${ }^{1}$ iD , Yasin Çilhoroz ${ }^{2}$ (D) , Enver Bozdemir ${ }^{3}$ (D)
}

${ }^{1}$ Ankara Hacı Bayram Veli Üniversitesi, Sağlık Yönetimi, Ankara, Türkiye

${ }^{2}$ Hacettepe Üniversitesi, Sağlık Yönetimi, Ankara, Türkiye

${ }^{3}$ Düzce Üniversitesi, Sağlık Yönetimi, Düzce, Türkiye

İlknur ARSLAN ÇiLHOROZ, Uzm.

Yasin ÇilLHOROZ, Arş. Gör.

Enver BOZDEMIR, Prof. Dr.

\section{Correspondence: Yasin ÇiLHOROZ}

Hacettepe Üniversitesi, Sağlı Yönetimi, Ankara,

Türkiye

Phone: +903122976356

E-mail: yasin.cilhoroz@hacettepe.edu.tr

$\begin{array}{ll}\text { Received } & : 03 \text { June } 2020 \\ \text { Accepted } & : 05 \text { September } 2020\end{array}$

\section{ABSTRACT}

Aim: COVID-19 pandemic has been one of the biggest threats to human health globally. Since the studies investigating the effects and treatment methods of this pandemic have also increased over time, systematical analysis of these studies has become a requirement. In this sense, the aim of this study was to analyze the studies on COVID-19 using the science mapping technique systematically.

Study Design: For this purpose, Scopus, Web of Science and PubMed databases were searched. As a result of this database search, a total of 10746 publications were collected. VOSviewer, Cite Space, and Carrot Search softwares were used to analyze the collected publications. These softwares have been used in bibliometric studies to ensure that the results are visualized according to authors, keywords, countries, and journals.

Results: Results of the analysis showed that the country contributing the most to the field was China, and the journal was "The Lancet". Besides, the author who has the highest number of publications in the field was Chen NS according to the CiteSpace software, and Liu Y according to the Vosviewer software program.

Conclusion: Accordingly, the results of this study were considered to be a guide for the upcoming studies.

Keywords: Pandemic, COVID-19, bibliometric analysis, science mapping technique

\section{COVID-19 Pandemisi Üzerine Yapılan Çalışmaların Bilim Haritalama Tekniğiyle Analizi}

\section{ÖZET}

Amaç: Küresel anlamda insan sağlığına yönelik en büyük tehditlerden biri COVID-19 pandemisi olmuştur. Zamanla bu hastalığın etkileri ve tedavi yöntemleri konusunda yapılan çalışmalar da artış göstermiştir. Bu durum bu çalışmaların sistematik olarak analiz edilmesini gerekli kılmaktadır. Bu anlamda bu çalışmanın amacı, COVID-19 konusunda yapılan çalışmaların bilim haritalama tekniğine göre sistematik olarak analiz edilmesidir.

Çalışma Planı: Bu amaçla, son yıllarda bu alanlardaki yayınlarla ilgili bilgiler Scopus, Web of Science ve Pubmed veri tabanlarından elde edilmiştir. Veri tabanlarının taranması sonucunda toplamda 10746 yayına ulaşılmışıı. Ulaşılan yayınlar, VoSViewer, CiteSpace ve Carrot Search yazılım programları yoluyla analiz edilmiştir. Bu yazılım programları bibliyometrik çalışmalarda ve sonuçların yazarlara, anahtar kelimelere, ülkelere ve dergilere göre görselleştirilmesini sağlamak için kullanılmıştır.

Bulgular: Gerçekleştirilen analiz sonucunda alana en fazla katkı sağlayan ülkenin Çin, derginin ise "The Lancet" olduğu görülmüştür. Bunun yanısıra en fazla yayın yapan yazar CiteSpace yazıım programına göre Chen NS, Vosviewer veri tabanına göre Liu Y olmuştur.

Sonuç: Buna göre, daha sonra yapılacak çalışmalar için bu çalışmanın bulgularının rehberlik edebileceği düşünülmektedir.

Anahtar Kelimeler: Pandemi, COVID-19, bibliyometrik analiz, bilim haritalama tekniği 
$\mathbf{F}$ rom past to present, viral diseases emerge as a serious issue for public health continuously. In the past two decades, various viral outbreaks have occurred such as severe acute respiratory syndrome coronavirus (SARS-CoV) between 2002-2003 and H1N1 influenza in 2009. Recently, Middle East respiratory syndrome coronavirus (MERS-CoV) appeared firstly in Saudi Arabia in 2012. Lastly, in December 2019, an outbreak of a new coronavirus (Covid-19) occurred in Wuhan, China (1). As of May 15, 2020, COVID-19 caused approximately 4.5 million cases and 300 thousand deaths worldwide (2). WHO announced it as a pandemic after a large number of COVID-19 cases were identified in many countries outside of China in a very short time (3).

Although COVID-19 seems likely to be transmitted from animals to humans in relation to a large seafood market where live wild animals are also sold, the disease was found to be transmitted from person to person over time (4). (Li et al., 2020). COVID-19 has a number of symptoms that damage the human respiratory system. However, COVID-19 occurs after a stated incubation period of approximately 5.2 days $(4,5)$ (Rothan \& Byrareddy, 2020; Li et al., 2020). The period from the onset of COVID-19 symptoms to death varies between 6-41 days, with an average of 14 days. This period depends on the age of the patient and the situation of the immune system. This period is shorter especially in patients over the age of 70 compared to those under 70 (6). The most common symptoms at the onset of COVID-19 disease are fever, cough, and fatigue. Apart from these, there are sputum, headache, hemoptysis, diarrhea, difficulty breathing, and lymphopenia $(6,7,8)$. The most preferred diagnostic methods for COVID-19 based on these symptoms are PCR (polymerase chain reaction) test and chest radiography or CT (computer tomography) test. These methods ensure the detection of even a small number of viruses $(9,10)$.

After the diagnosis of COVID-19 disease, the next step is the treatment of the disease. At this stage, the isolation of the patient is a priority. Thereafter, treatment procedures start. There is currently no specific drug or vaccine for COVID-19. However, some existing drugs such as oseltamivir, lopinavir, ritonavir, ganciclovir and their compositions are used to treat the disease $(11,12,52)$.

To ensure hand hygiene, to keep at least a 3-meter social distance from other people, to stay away from crowded areas, not to touch the eyes, nose, and mouth with hands, to stay isolated at home, to inform the health institution immediately if there are symptoms of COVID-19, and to obey the recommendations of national and international organizations are the measures to be protected from COVID 19 (13).

The literature search showed that many studies related to COVID-19 have been carried out since December 2019 (14 $, 15,16,17,18,19,20,21,22,23,24,25,26,27)$.

Despite the fact that the main focus of these studies is the COVID-19 pandemic, the associated factors, countries in which they were conducted, the number of authors, etc. A systematical analysis of these studies has become a requirement, in order to get information about these studies in a simple manner. In this sense, the purpose of this study was to analyze the studies on COVID-19 using the science mapping technique systematically.

\section{Study Design}

This section explains the purpose, significance and problem of the research, the data collection techniques, and the analysis methods.

This study aimed to analyze the studies on COVID-19 using the science mapping technique systematically.

Advantages of doing bibliometric analysis for the purposes of this study are to provide a better understanding of the structure of scientific data; to give a theoretical opportunity to define, to analyze and evaluate the literature on this subject; to provide valuable information about the chronological development of this research area (past, present, and future); to enable scientists to identify scientifically influential authors, articles, journals, topics, and citations, and to provide the opportunity to determine the degree of interaction among authors, scientific articles and journals, summarize big data sets, and to identify popular issues and research trends.

The model of the study is shown in Figure 1.

"Scopus, Web of Science and PubMed" academic publication databases were used as a data collection method. The data were obtained on May 17, 2020. Each publication in the databases contains many details including the year of publication, authors, authors' fields, titles, summary, source, topic categories, and references. 
The keyword used in the publication search was "COVID-19". Quotation marks are included in the search term. Using quotation marks helps to get correct results (28). As a result of the search, it was reached 7,287 studies in Scopus, 3,093 studies in Web Of Science, and 366 studies in PubMed. A total of 10,746 studies were analyzed.

Reading all these studies seems not possible for those who are interested in the field. Rational readers have rational choices in the face of this important knowledge. One of these choices is to use bibliometric analysis techniques (29).

The searching screen of the research is shown in Table 1.

If the same search strategy is performed on a different date, the results may differ slightly. This difference is due to the fact that databases are constantly updated. The criteria and details about this study are presented in Table 2 .

The Bibliometric analysis allows an exchange of information between two or more research areas and an in-depth study of the research areas (29). In this study, VoSViewer, CiteSpace and Carrot Search softwares, which are modern visual mapping techniques, were used together. Bibliometric analysis was used to explore the four research aspects from the aspects provided in Figure 2.

VoSViewer was developed by Eck and Waltman (2014) at Leiden University in the Netherlands. With a user-friendly interface, VoSViewer offers both the basic functionality required to visualize bibliometric networks and advanced features to create these networks (30). CiteSpace software was developed by Chaomei Chen at Drexel University in the USA. CiteSpace is a more specialized tool capable of categorizing data into different time subclasses and visualizing networks using various arrangements. As Chen describes, the CiteSpace software program is a true " $X$-ray machine for literature" and allows users to discover the intellectual field of an information field, see how it evolved over time, and identify research points and boundary directions in a particular area (31). Both software are available online for free and are effective in data visualization (32). These programs have also been used to create cocitation networks, co-authoring networks, co-generation networks, and explosion detections.

Carrot Search is characterized by several features, which are useful for creating custom web search clustering systems. The clear data-driven process of information manipulation defined within decreases the time and effort required for building software and allows performing rapid experiments with search results clustering through component reuse and facilitation of their development (33).

\section{Results}

Content Analysis

Table 3 shows the top 10 most cited studies on COVID-19. The top 10 most cited studies belong to the Scopus database. In the study titled "Clinical features of patients infected with the novel coronavirus 2019 in Wuhan, China" conducted by Huang et al (2020), the researchers concluded that COVID-19 infection caused severe respiratory disease and the intensive care acceptance was high. The second study which is conducted by Zhu et al. (2020) concluded that COVID-19 was the seventh member of the coronavirus family that infects humans as both MERS-CoV and SARS-CoV did. Chen et al. (2020) have revealed that COVID-19 infection was more likely to affect older men with comorbidity, and could cause serious and fatal respiratory diseases such as acute respiratory distress syndrome. Guan et al. (2020) stated that in the first 2 months of the current outbreak, COVID-19 spread rapidly to China and caused diseases that have different degrees. Chan et al. (2020) emphasized that this new coronavirus was consistent with person-to-person transmission in hospitals, houses and infected travelers in other geographic areas.

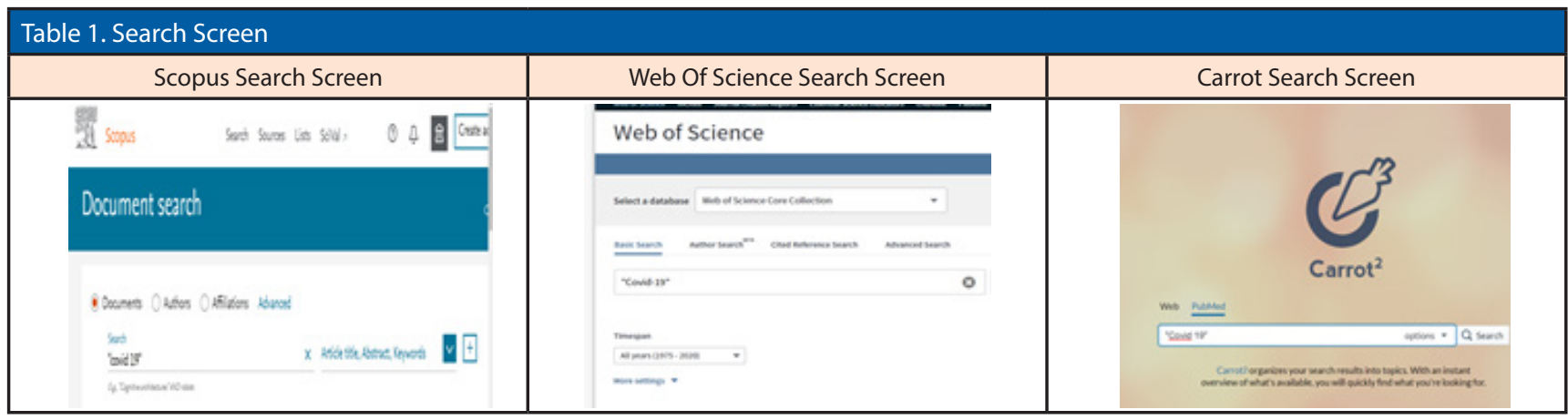




\begin{tabular}{|c|c|c|c|}
\hline \multicolumn{2}{|l|}{ Criteria } & \multicolumn{2}{|l|}{ Details } \\
\hline \multirow{3}{*}{ Database } & wOS & Article Topic & Citespace \\
\hline & Scopus & $\begin{array}{l}\text { Article title, Summary, } \\
\text { Keywords }\end{array}$ & Vosview \\
\hline & PubMed & Available Options & Carrot Search \\
\hline \multicolumn{2}{|l|}{ Title } & \multicolumn{2}{|l|}{ "Covid-19" } \\
\hline \multicolumn{2}{|l|}{ Timeframe } & \multicolumn{2}{|l|}{$2019-2020$} \\
\hline \multicolumn{2}{|c|}{ Document Type } & \multicolumn{2}{|c|}{$\begin{array}{l}\text { Articles, Books, Book Chapters, Papers, } \\
\text { Reviews }\end{array}$} \\
\hline \multicolumn{2}{|c|}{ Research History } & \multicolumn{2}{|l|}{17 May 2020} \\
\hline
\end{tabular}

\begin{tabular}{|c|c|c|c|}
\hline Authors & Title of the Study & Citations & Magazine \\
\hline $\begin{array}{l}\text { Huang et al., } \\
2020\end{array}$ & $\begin{array}{l}\text { Clinical features of patients } \\
\text { infected with } 2019 \text { novel } \\
\text { coronavirus in Wuhan, China }\end{array}$ & 1250 & The Lancet \\
\hline Zhu et al., 2020 & $\begin{array}{l}\text { A novel coronavirus from } \\
\text { patients with pneumonia in } \\
\text { China, } 2019\end{array}$ & 749 & $\begin{array}{l}\text { New } \\
\text { England } \\
\text { journal of } \\
\text { medicine }\end{array}$ \\
\hline $\begin{array}{l}\text { Chen et al., } \\
2020\end{array}$ & $\begin{array}{l}\text { Epidemiological and clinical } \\
\text { characteristics of } 99 \text { cases } \\
\text { of } 2019 \text { novel coronavirus } \\
\text { pneumonia in Wuhan, China: a } \\
\text { descriptive study }\end{array}$ & 679 & The Lancet \\
\hline $\begin{array}{l}\text { Guan et al., } \\
\quad 2020\end{array}$ & $\begin{array}{c}\text { Clinical characteristics of } \\
\text { coronavirus disease } 2019 \text { in } \\
\text { China }\end{array}$ & 615 & $\begin{array}{l}\text { New } \\
\text { England } \\
\text { journal of } \\
\text { medicine }\end{array}$ \\
\hline $\begin{array}{l}\text { Chan et al., } \\
2020\end{array}$ & $\begin{array}{l}\text { A familial cluster of pneumonia } \\
\text { associated with the } 2019 \text { novel } \\
\text { coronavirus indicating person- } \\
\text { to-person transmission: a study } \\
\text { of a family cluster }\end{array}$ & 473 & The Lancet \\
\hline $\begin{array}{l}\text { Zhou et al., } \\
\quad 2020\end{array}$ & $\begin{array}{l}\text { A pneumonia outbreak } \\
\text { associated with a new } \\
\text { coronavirus of probable bat } \\
\text { origin }\end{array}$ & 455 & Nature \\
\hline Wu et al. 2020 & $\begin{array}{l}\text { Characteristics of and Important } \\
\text { Lessons from the Coronavirus } \\
\text { Disease } 2019 \text { (COVID-19) } \\
\text { Outbreak in China: Summary of } \\
\text { a Report of } 72314 \text { Cases from } \\
\text { the Chinese Center for Disease } \\
\text { Control and Prevention }\end{array}$ & 406 & $\begin{array}{l}\text { JAMA - } \\
\text { Journal } \\
\text { of the } \\
\text { American } \\
\text { Medical } \\
\text { Association }\end{array}$ \\
\hline Lu et al., 2020 & $\begin{array}{l}\text { Genomic characterization and } \\
\text { epidemiology of } 2019 \text { novel } \\
\text { coronavirus: implications for } \\
\text { virus origins and receptor } \\
\text { binding }\end{array}$ & 399 & The Lancet \\
\hline $\begin{array}{l}\text { Holshue et al., } \\
\qquad 2020\end{array}$ & $\begin{array}{l}\text { First case of } 2019 \text { novel } \\
\text { coronavirus in the United States }\end{array}$ & 321 & $\begin{array}{l}\text { New } \\
\text { England } \\
\text { journal of } \\
\text { medicine }\end{array}$ \\
\hline $\begin{array}{l}\text { Zhou et al., } \\
2020\end{array}$ & $\begin{array}{l}\text { Clinical course and risk factors } \\
\text { for mortality of adult inpatients } \\
\text { with COVID-19 in Wuhan, China: } \\
\text { a retrospective cohort study }\end{array}$ & 312 & The Lancet \\
\hline
\end{tabular}

In a study by Zhou et al. (2020), the researchers confirmed that COVID-19 was $96 \%$ identical to a bat coronavirus at the whole genome level and used the same cell entry receptor (angiotensin-converting enzyme II (ACE2)) as the SARS-CoV. Wu et al. (2020) emphasized the significance of responding effectively such as proactive investment in public health infrastructure during the fight against COVID-19. Lu et al. (2020) found that COVID-19 was different from SARS-CoV, which will be considered as a new human-infected betacoronavirus. The study of Holshue et al. (2020) describes the clinical features of the first reported patient with COVID-19 infection in the United States and focuses on the importance of clinicians who reveal a travel history of COVID-19 infected patient or exposure to patients with COVID-19. Zhou et al. (2020) also indicated that aging, high SOFA score and D-dimer higher than $1 \mu \mathrm{g} / \mathrm{mL}$ are potential risk factors that can help clinicians to prognose the COVID-19 infected patients early $(8,9,12,34,35,36,37,38,50,51)$.

\section{Analysis Based on Topic Categories}

According to Figure 3, there are categories in the image created using the CiteSpace software with data from the Web of Science database. Accordingly, the highest number of publications was conducted in the Internal Medicine field with 143 publications. This is followed by Virus Science (34), Nuclear Radiology, and Medical Imaging (30), Surgery (27), and Infectious Diseases (26).

The topic categories of the publications related to COVID-19 are given in Table 4. According to the Web of Science database, 728 publications were conducted in the field of Medicine. This was followed by Public Environmental Health (190), Surgery (183), Radiology and Nuclear Medicine, and Communicable Diseases. According to the Scopus database, $62 \%$ of the publications were conducted in the field of Medicine, 9.4\% from other fields, $6.7 \%$ in Biochemistry, Genetics, and Microbiology, $6.3 \%$ in Immunization and Microbiology. 


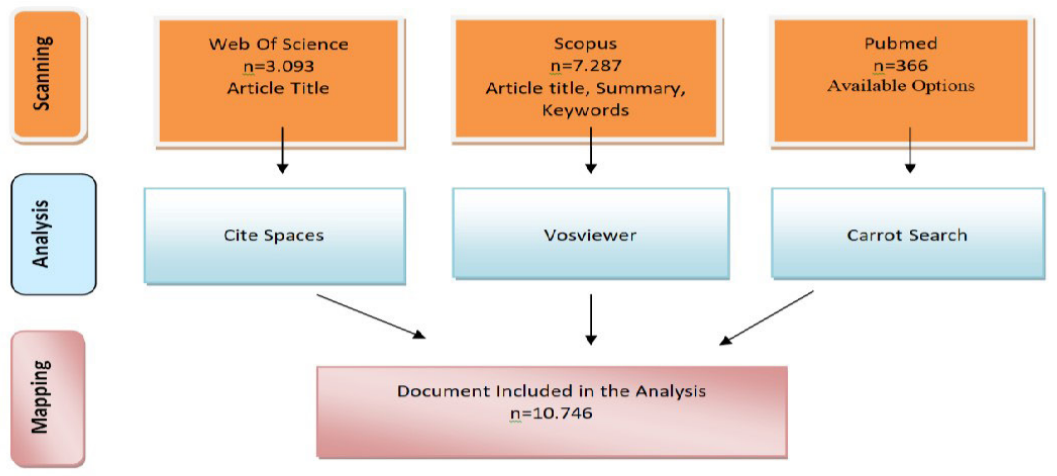

Figure 1. Model of the Study

In this study, "Scopus, Web of Science and PubMed" academic publication databases were used as a data collection method. The data were obtained on May 17, 2020. Each publication in the databases contains many details including the year of publication, authors, authors' fields, titles, summary, source, topic categories, and references.

"COVID-19" was the keyword used in the publication search. Quotation marks are included in the search term. Using quotation marks helps to get correct results (28). As a result of the search, 7,287 studies were accessed in Scopus, 3,093 studies in Web Of Science, and 366 studies in PubMed. A total of 10,746 studies were analyzed.
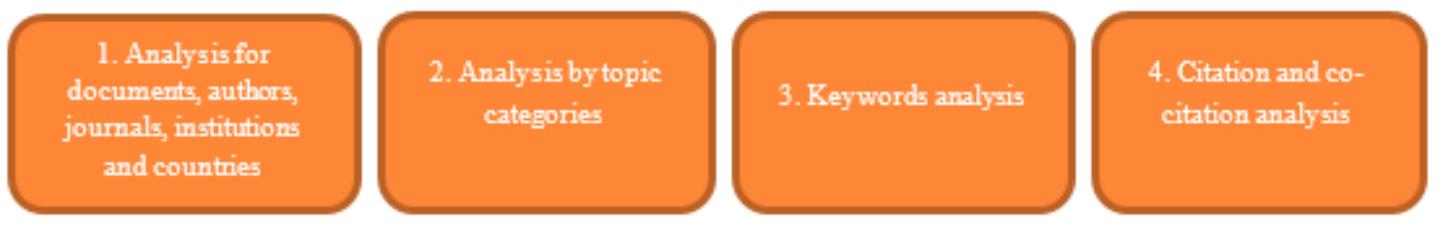

\section{Figure 2. The Analysis Process of the Research}

In this study, VoSViewer, CiteSpace ve Carrot Search softwares, which are modern visual mapping techniques, were used together. Bibliometric analysis was used to explore the four research aspects from the following aspects that are provided in Figure 2.

Figure 3. Analysis of Subject Categories According to Cite Space Analysis

According to Figure 3, there are categories in the image created using the CiteSpace software with data from the Web of Science database. Accordingly, the highest number of publications was conducted in the Internal Medicine field with 143 publications. This is followed by Virus Science (34), Nuclear Radiology, and Medical Imaging (30), Surgery (27), and Infectious Diseases (26). 
Table 4. Topic Categories of COVID-19 Related Publications

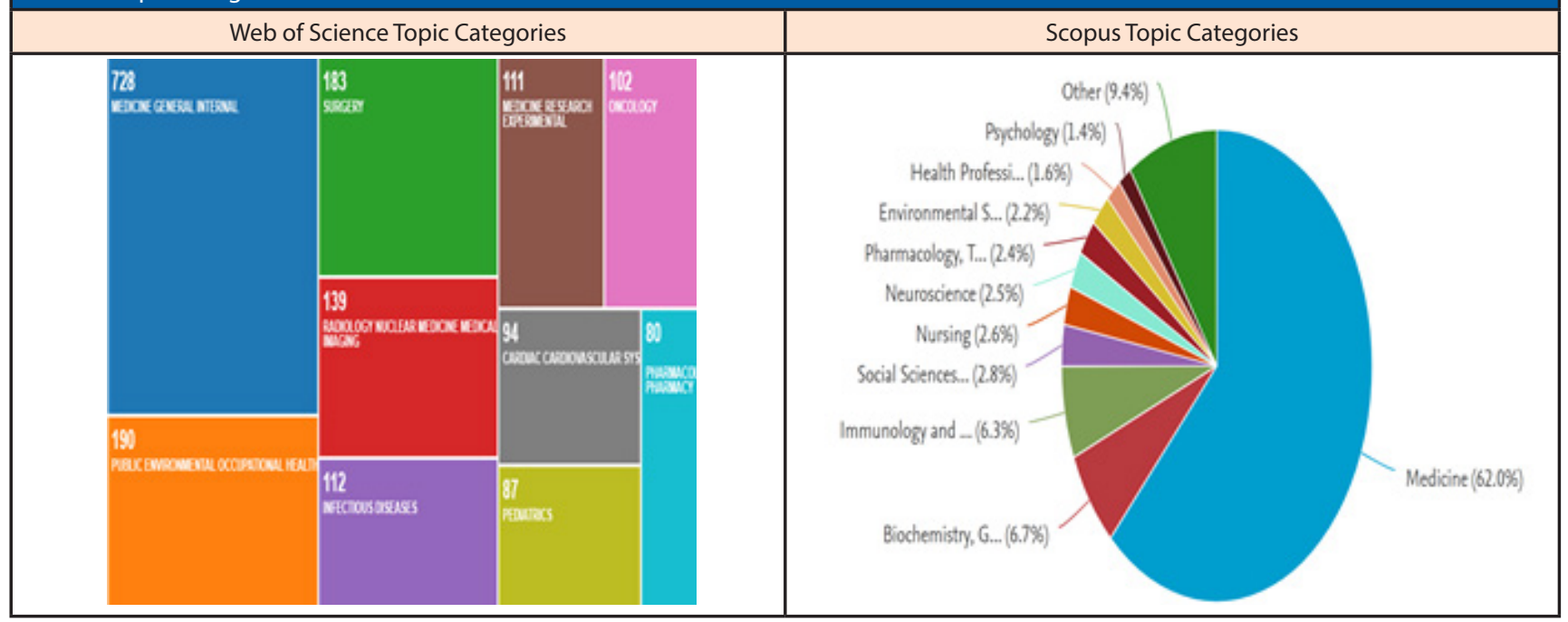

\section{Keyword Based Mapping}

Figure 4 shows the most used keywords in COVID-19 studies, which were determined with the VoSwiever program keyword analysis of the data from the Scopus database. The threshold value in the program is selected as 10. The most commonly used terms were Covidien (682 times), new coronavirus (186 times), pneumonia (180 times), and Wuhan (137 times).

Table 5 shows 366 studies that are accessed through Carrot Search analysis using the PubMed database. The most commonly used keywords were Object (157 times), Covid-19 Pandemic (59 times), Covid-19 Patients (49 times), Disease (27 times), and Coronavirus Covid-19 (22 times).

Figure 5 shows the most commonly used keywords in the analysis of keywords performed via CiteSpace software using the Web of Science database, which are COVID 19 (180 times), Coronavirus (110 times), Sars-Cov-2 (79 times) and Pneumonia (60 times). When the word groups are examined, clusters were 0 : Respiratory failure, 1 : Sleep quality, 2: Organ protective effect, 3: Covid-19 Infection, 4: operatory consideration, 5: Global transplant perspective.

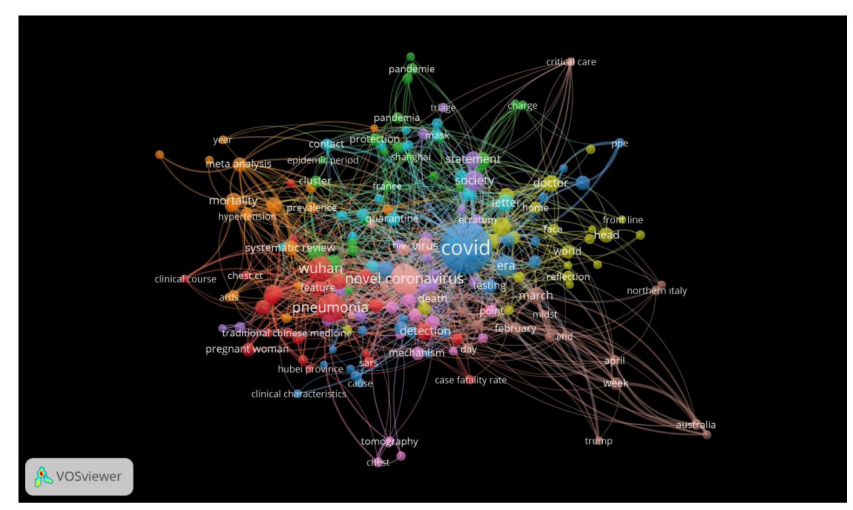

Figure 4. Keyword Analysis with Vosviewer (When 12.087 term minimum 10 is selected, 310 term thresholds meet.)

In Figure 4, for the detection of the most used keywords in COVID-19 studies, the data from the Scopus database were subjected to keyword analysis in the VoSViewer software. The threshold value in the program is selected as 10 . The most commonly used terms were Covidien (682 times), new coronavirus (186 times), pneumonia (180 times), and Wuhan (137 times).

\section{Attribution and Common Attribution Based Mapping}

As Eck and Waltman (2014) mentioned, citation analysis is an effective way to analyze the communication within the academic community, the structure of science from an interdisciplinary perspective, and to explore new knowledge-generating mechanisms. 


Keyword Analysis with Treemap

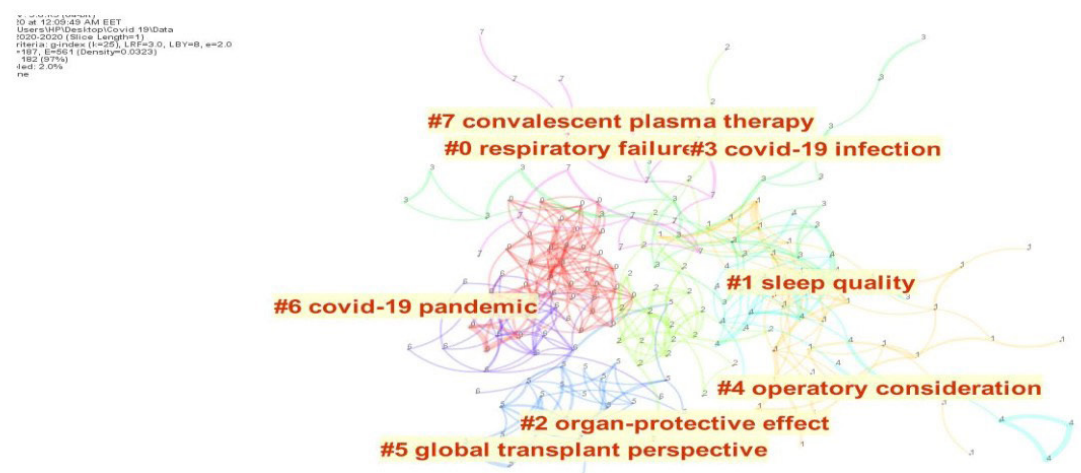

Figure 5. Keyword Analysis with CiteSpace

In Figure 5, COVID-19 (180 times), Coronavirus (110 times), Sars-Cov-2 (79 times), Pneumonia (60 times) were the most commonly used keywords in the analysis of keyword performed via CiteSpace software using Web of Science database. When the word groups are examined, clusters were 0: Respiratory failure, 1: Sleep quality, 2: Organ protective effect, 3: Covid-19 Infection, 4: operatory consideration, 5: Global transplant perspective.

Citations are also extremely important to determine the significance of a scientific article. There is a strong relationship between the frequency of citations and the unique scientific value of the article. The number of citations is the main factor reflecting the quality of an article (40). The citation should be considered as the criterion of the publication value (39). Obviously, older publications are more likely to get more citations than newer publications, but this should not be taken into consideration in the sense that the recently published studies will not have a significant impact in this area (41).
In Figure 6, the analysis of data from the Scopus database was performed in the VosViewer software. Accordingly, the most cited author was Liu, Y with 1634 citations. This was followed by Wang, W (1407), Zhang I (1334), Song J (1172), and Wang J (1157).

In Figure 7, the data from the Scopus database were analyzed by the VosViewer software. Accordingly, the authors who are in contact with each other were clustered into 5 groups. The most commonly cited author was found as $\mathrm{Li}$, $\mathrm{X}$ with 737 common citations. 


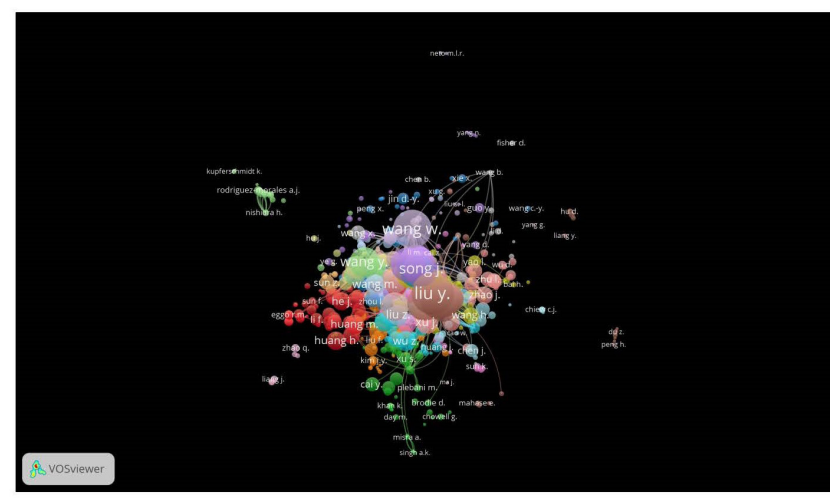

Figure 6. Citation Analysis of Authors with Vosviewer (cluster view: 763 authors meet the 593 threshold when the minimum value of 3 is selected.)

In Figure 6, the analysis of data from the Scopus database was performed in the VoSViewer software. Accordingly, the most cited author was Liu, Y with 1634 citations. This was followed by Wang, W (1407), Zhang I (1334), Song J (1172), and Wang J (1157).

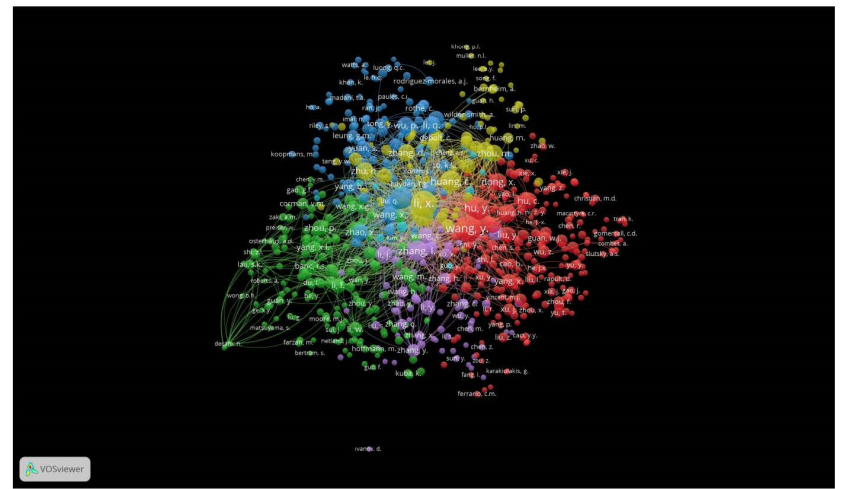

Figure 7. Co-Citation Analysis of Authors with Vosviewer (cluster view: when 32,957 minimum value is selected 20 meets 719 threshold.)

In Figure 7, the analysis of the data from the Scopus database was performed in the VoSViewer software. Accordingly, the authors who are in contact with each other were clustered into 5 groups. The most commonly cited author is $\mathrm{Li}, \mathrm{X}$ with 737 common citations.

The topic categories of the publications related to COVID-19 were provided in Table 4. According to the Web of Science database, 728 publications were conducted in the field of Medicine.

According to Figure 8, the most cited author was Chen NS with 101 citations using the CiteSpace software when the data from Web of Science database were analyzed using the CiteSpace software. This was followed by Wang DW (89), Li Q (86), Chan JFW (85), Anonymous (84).

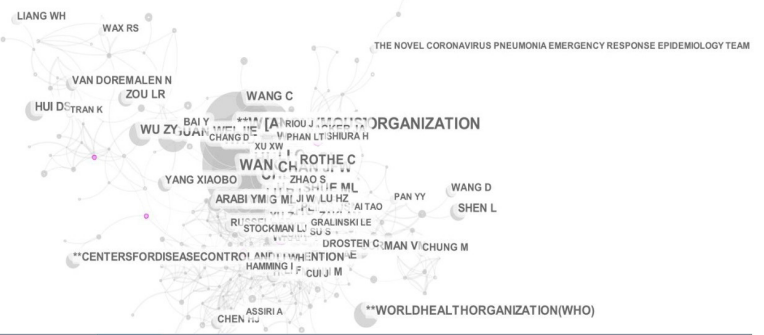

Figure 8. Citation Analysis of Authors with CiteSpace

According to Figure 8, the most cited author using the CiteSpace software with data from the Web of Science database was Chen NS with 101 citations. This was followed by Wang DW (89), Li Q (86), Chan JFW (85), Anonymous (84).

In Figure 9, the data from the Scopus database was analyzed in the VosViewer software. Accordingly, the journal that received the highest number of citations from publications in the field of COVID-19 was "The Lancet" with 3986 citations. This was followed by New England Journal of Medicine (2530), Journal of American Medical Association (1113), Radiology (872) and Journal of Medical Virology (756).

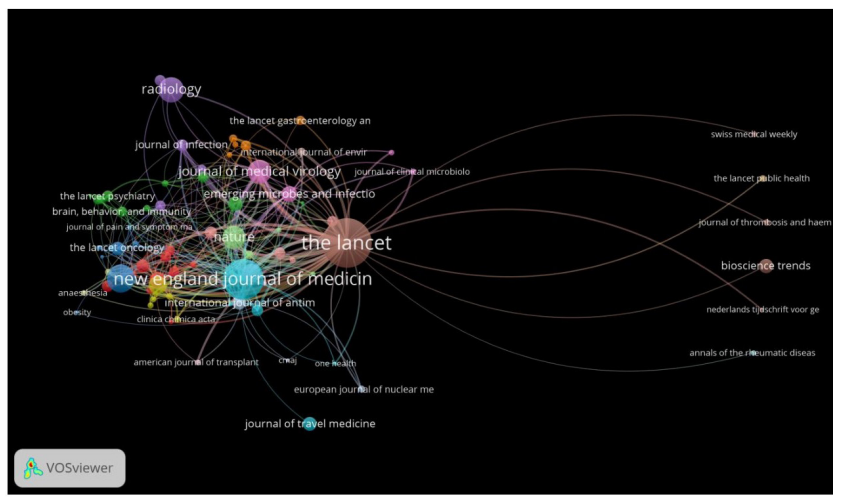

Figure 9. Citation Analysis of Journals with Vosviewer (cluster view: 676 journals meet 93 thresholds when the minimum value is selected 5 )

In Figure 9, data from Scopus database performed in the VoSViewer software. Accordingly, the journal that received the highest number of citations from publications in the field of COVID-19 was "The Lancet" with 3986 citations. This was followed by New England Journal of Medicine (2530), Journal of American Medical Association (1113), Radiology (872) and Journal of Medical Virology (756).

The analysis performed in the CiteSpace software program with the data from Web of Science database was as in Figure 10. According to this, the journal which received the most citation was "The Lancet" with 296 citations. This is followed by New England Journal of Medicine (238), Journal of American Medical Association (156), Nature (112) and Journal of Medical Virology (81). 


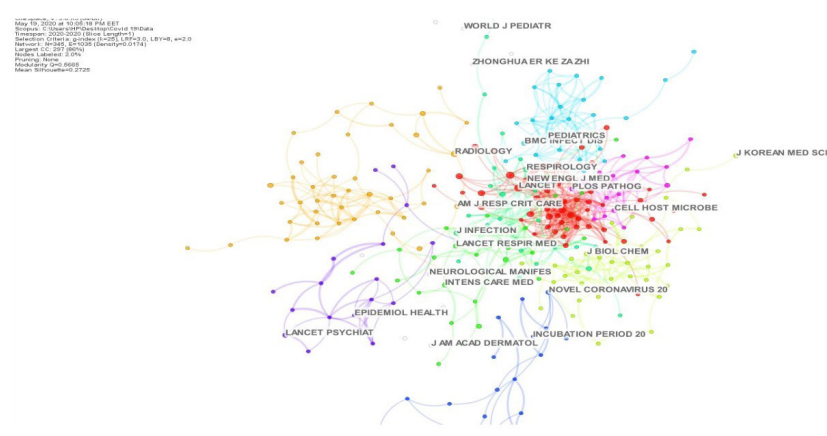

Figure 10. Citation Analysis of Journals with Cite Space

The analysis performed in the CiteSpace software program with the data from Web of Science database was as in Figure 10. According to this, the journal which received the highest number of citations was "The Lancet" with 296 citations. This is followed by New England Journal of Medicine (238), Journal of American Medical Association (156), Nature (112) and Journal of Medical Virology (81).

Country analysis was performed with the data from Web of Science database using CiteSpace software program. Large circles show the most influential countries in the field, the degree of communication between countries and the links between the circles. Accordingly, China was the country with the highest number of citations in studies on COVID-19. This was followed by the USA with $129 \mathrm{ci}-$ tations, England with 74 citations, Italy with 60 citations, Canada with 29 citations and Germany with 26 citations.

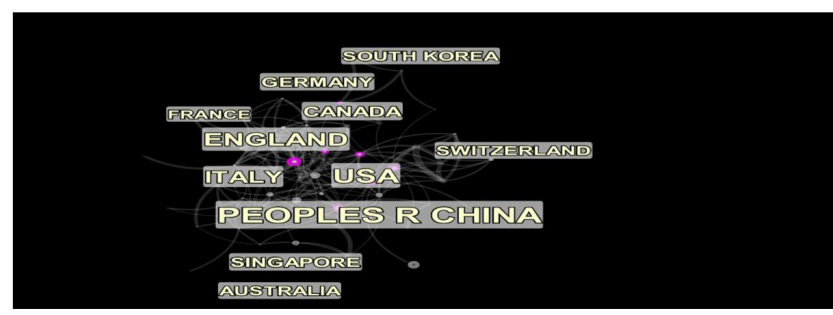

Figure 11. Citation Analysis of Countries with Cite Space

Country analysis was performed with data from Web of Science database using CiteSpace software. Large circles show the most influential countries in the field, the degree of communication between countries and the links between the circles. Accordingly, China was the country with the highest number of citations in studies on COVID-19. This was followed by the USA with 129 citations, England with 74 citations, Italy with 60 citations, Canada with 29 citations and Germany with 26 citations.

Analysis of the data from Scopus database was performed in VosViewer software provided in Figure 12. Citing countries tend to be close to each other. Countries with collaborative connectivity were clustered in 8 groups. The most cited country was China with 13,466 . This was followed by the USA (3782), England (1760), Hong Kong (1458) and Italy (1277).

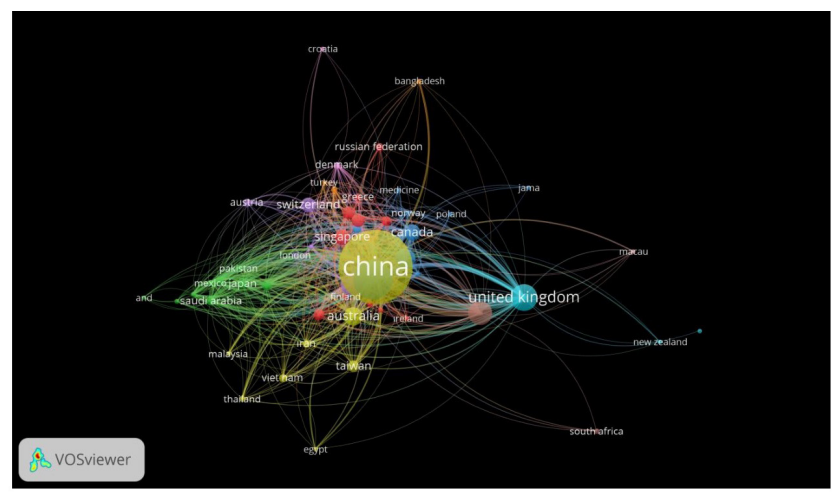

Figure 12. Citation Analysis of Countries with Vosviewer (53 meets threshold when minimum value 5 is selected from 271 countries.)

Analysis of data from Scopus database performed in VoSViewer software program provided in Figure 12. Citing countries tend to be close to each other. Countries with collaborative connectivity were clustered in 8 groups. The most cited country was China with 13,466. This was followed by the USA (3782), England (1760), Hong Kong (1458) and Italy (1277).

\section{Discussion and Conclusion}

This study was carried out to analyze the studies on COVID-19 according to the science mapping technique systematically. In this context, the data were obtained through Scopus, Web of Science, and PubMed databases. Then, the data were visualized using VosViewer, CiteSpace and Carrot Search softwares. When the categories of the publications related to COVID-19 were examined in the analysis performed with the CiteSpaces software, it was seen that the highest number of publications was conducted in the field of Medicine, then Virus Science, Nuclear Radiology, and Medical Imaging, Surgery and Communicable Diseases. According to the CiteSpace software program, the author who conducted the highest number of publications was Chen NS and according to the VosViewer software was Liu Y. According to the VoSViewer software, the most co-cited author was $\mathrm{Li}, \mathrm{X}$. Wang $\mathrm{W}$ was one of the most preferred authors in both citation and co-citation analysis. According to the VosViewer software, The Lancet was the journal having the highest number of publications in the field, and New England Journal of Medicine, Journal of American Medical Association, Radiology and Journal of Medical Virology follow next. According to CiteSpace analysis, The Lancet was again the journal having the highest citation, and New England Journal of Medicine, Journal of the American Medical Association, Nature and Journal of Medical Virology follow next. The first three journals were the same in both analysis programs. The most cited publications related to COVID-19 were collected in "The Lancet". 
COVID-19, Coronavirus (Sars-Cov-2), Pneumonia, and Infection were the most used keyword words in the analysis of the data obtained from the Web of Science database using the CiteSpace software. The most frequently used keywords in data obtained from the PubMed database using Carrot Search analysis were Object, Covid-19 Pandemic, Covid-19 Diseases, and Coronavirus. Finally, COVID, New Corona Virus, Pneumonia, and Wuhan were the most used keywords data from the Scopus using VoSViewer software. In line with these results, it was seen that the common keyword is "Covid-19". The most cited countries were China, the USA, the UK, Hong Kong, and Italy according to the VoSViewer program and according to the CiteSpace analysis; those were China, the USA, England, Italy, Canada, and Germany. Since the first 3 rankings were the same in both analyzes, China, the USA, and England can be considered to dominate the literature in the publications related to COVID-19. The reason why China has the highest number of publications is the fact that the disease started there first.

There are also previous studies including bibliometric and content analysis studies conducted on COVID-19 in the literature. A study conducted by Tran et al. (2020), showed that the highest number of publications was conducted in the USA, China, and European countries. In addition, the most discussed topics were emergency care and surgical guides, viral pathogens, and global responses (42). A study conducted by Golinelli et al. (2020) mainly focuses on the calculated Effect Scores of studies on COVID-19 (43). The highest Effect Score belongs to Huang et al. (2020). In another study conducted by Chahrour et al. (2020), studies published in PubMed and WHO databases were examined. As a result of the analysis, 564 publications were accessed. The country where the highest number of studies were conducted was found to be China $(8,44)$. The study by Hossain (2020) examined 422 studies. The study titled "Clinical features of patients infected with 2019 novel coronavirus in Wuhan, China" by Huang et al, (2020) in The Lancet (45) was the most cited publication. In a study conducted by Lou et al. (2020), 183 studies were examined through the PubMed database. The researchers found that the highest number of publications were conducted in China and published in the Journal of Medical Virology (46). In another study conducted by Hamidah et al. (2020), where the VoSViewer software program was used to visualize the data, 3513 publications were analyzed through the Scopus database (47). China was again the country where the most highest number of publications were conducted. The most used keywords were detected as coronavirus, pandemic and impact. In another study conducted by Nasab (2020), 92 publications were analyzed through the Web of Science database. Again, the highest number of studies were conducted in China and VoSViewer software program was used to visualize the data (48). In Dehghanbana (2020), 923 publications were reached through Scopus database (49). China and the USA were the countries which contribute the highest number of publications. The Lancet and BMJ Clinical Research Ed became the journals having the highest number of publications in the field. In the study mentioned, VoSViewer was the software used to visualize the data as well. It was seen that these studies were mostly literature reviews and WoSViewer was the commonly used software to visualize the data. Since CiteSpace, Carrot Search and VoSViewer were used together, this study differs from other studies.

The COVID-19 pandemic continues to threaten public health globally (53). To solve such problems, the problem is required to be comprehended deeply and its solutions should be investigated. For this reason, the role of scientific studies is crucial. In this way, the correct information will be obtained by studies relating to all aspects of COVID-19 pandemic. This study provides a global bibliometric evaluation of studies on COVID-19 that can facilitate ongoing and future research. Visualization of the data in this study provides an important convenience for the readers. At the same time, this study serves as a guideline for other researchers for future studies. Academic and professional efforts to understand and to deal with COVID-19 will continue to increase with the knowledge that is available today, that will continue to evolve over time and that enrich science and societies globally.

\section{References}

1. Cascella, M., Rajnik, M., Cuomo, A., Dulebohn, SC, \& Di Napoli, R. Features, evaluation and treatment coronavirus (COVID-19). In Statpearls, StatPearls Publishing, 2020.

2. WHO. WHO coronavirus disease (COVID-19) Dashboard 2020a. https://covid19.who.int/ . (Accessed 15 May 2020).

3. WHO. WHO announces COVID-19 outbreak a pandemic, 2020b. http://www.euro.who.int/en/health-topics/health-emergencies/ coronavirus-covid-19/news/news/2020/3/who-announces-covid19-outbreak-a-pandemic . (Accessed 15 May 2020).

4. Li Q, Guan X, Wu P, Wang X, Zhou L et al. Early transmission dynamics in Wuhan, China, of novel coronavirus - infected pneumonia. New England Journal of Medicine 2020; 382(13): 1199-1207.

5. Rothan HA, Byrareddy SN. The epidemiology and pathogenesis of coronavirus disease (COVID-19) outbreak. Journal of Autoimmunity 2020; 102433.

6. Wang W, Tang J, Wei F. Updated understanding of the outbreak of 2019 novel coronavirus (2019-nCoV) in Wuhan, China. Journal of Medical Virology 2020; 92 (4): 441-447. doi: 10.1002/jmv.25689

7. Ren LL, Wang YM, Wu ZQ, Xiang ZC, Guo L, Xu T et al. Identification of a novel coronavirus causing severe pneumonia in human: a descriptive study. Chinese medical journal. 
8. Huang C, Wang Y, Li X, Ren L, Zhao J et al. Clinical features of patients infected with 2019 novel coronavirus in Wuhan, China. Lancet 2020; 395 (10223): 497-506. doi: 10.1016/S0140- 6736(20)30183-5

9. Zhou F, Yu T, Du R, Fan G, Liu Y et al. Clinical course and risk factors for mortality of adult inpatients with COVID-19 in Wuhan, China: a retrospective cohort study. Lancet 2020; 395 (10229): 1054-1062. doi: 10.1016/S0140-6736(20)30566-3

10. Fang $Y$, Zhang $H$, Xie J, Lin M, Ying L et al. Sensitivity of chest CT for COVID-19: comparison to RT-PCR. Radiology 2020; 200432.

11. 11. H Lu, Drug treatment options for the 2019-new coronavirus (2019-nCoV), Biosci. Trends (2020), https://doi.org/10.5582/ bst.2020.01020.

12. 12. Chen N, Zhou M, Dong X, Qu J, Gong F et al. Epidemiological and clinical characteristics of 99 cases of 2019 novel coronavirus pneumonia in Wuhan, China: a descriptive study. The Lancet 2020; 395 (10223): 507-513.

13. WHO. Protecting yourself and others from the spread COVID-19, 2020c. https://www.who.int/emergencies/diseases/novelcoronavirus-2019/advice-for-public . (Accessed 15 May 2020).

14. Leite $\mathrm{H}$, Gruber T, Hodgkinson IR. Flattening the infection curve - understanding the role of telehealth in managing COVID-19. Leadership in Health Services, 2019.

15. Wong HYF, Lam HYS, Fong AHT, Leung ST, Chin TWY et al. Frequency and distribution of chest radiographic findings in COVID-19 positive patients. Radiology 2020; 201160.

16. Her M. Repurposing and reshaping of hospitals during the COVID-19 outbreak in South Korea. One Health 2020; 100137.

17. Şahin M. Impact of weather on COVID-19 pandemic in Turkey. Science of The Total Environment 2020; 138810.

18. Bettinelli G, Delmastro E, Salvato D, Salini V, Placella G. Orthopaedic patient workflow in CoViD-19 pandemic in Italy. Journal of Orthopaedics 2020; 22: 158.

19. Dexter F, Elhakim M, Loftus RW, Seering MS, Epstein RH. Strategies for daily operating room management of ambulatory surgery centers following resolution of the acute phase of the COVID-19 pandemic. Journal of Clinical Anesthesia 2020; 109854.

20. Ostaszewski M, Mazein A, Gillespie ME, Kuperstein I, Niarakis A et al. COVID-19 Disease Map, building a computational repository of SARS-CoV-2 virus-host interaction mechanisms. Scientific data 2020; 7 (1): 1-4.

21. Tang Y, Wang S. Mathematic modeling of COVID-19 in the United States. Emerging Microbes \& Infections 2020; (just accepted) 1-10.

22. 22.Kilicaslan A, Kekec AF, Eren AS, Uzun ST. Peripheral nerve blocks in a patient with suspected COVID-19 infection. Journal of Clinical Anesthesia 2020.

23. Deng W, Xu Y, Kong Q, Xue J, Yu P wt al. Therapeutic efficacy of Pudilan Xiaoyan Oral Liquid (PDL) for COVID-19 in vitro and in vivo. Signal Transduction and Targeted Therapy 2020; 5(1): 1-3.

24. Jeyabaladevan P. COVID-19: an FY1 on the frontline. Medical Education Online 2020; 25(1): 1759869.

25. Gross A, Thiemig D, Koch FW, Schwarz M, Gläser S et al. CT appearance of severe, laboratory-proven coronavirus disease 2019 (COVID-19) in a Caucasian patient in Berlin, Germany. In RöFo-Fortschritte auf dem Gebiet der Röntgenstrahlen und der bildgebenden Verfahren 2020; 192(5): 476-477.

26. Mansoor S, Kelly S, Murphy K, Waters A, Siddiqui NS. COVID-19 pandemic and the risk of infection in multiple sclerosis patients on disease modifying therapies: "what the bleep do we know?". The Egyptian Journal of Neurology, Psychiatry and Neurosurgery 2020; 56: 1-3.

27. Ceylan Z. Estimation of COVID-19 prevalence in Italy, Spain, and France. Science of The Total Environment 2020; 138817.
28. van Nunen K, Li J, Reniers G, Ponnet K. Bibliometric analysis of safety culture research. Safety science 2018; 108: 248-258.

29. Kurutkan MN, Orhan F. Analysis of health policy subject with science mapping techniques. IKSAD Publishing House, Ankara, 2018.

30. Van Eck NJ, Waltman L. Visualizing bibliometric networks. In Measuring scholarly impact, Springer, 2014; 285-320.

31. Chen C. CiteSpace: a practical guide for mapping scientific literature. Nova Science Publishers, Incorporated 2016.

32. Gong $\mathrm{R}$, Xue J, Zhao L, Zolotova O, Ji X et al. A Bibliometric analysis of green supply chain management based on the web of science (WOS) platform. Sustainability 2019; 11(12): 3459.

33. Stefanowski J, Weiss D. Carrot 2 and language properties in web search results clustering. In International Atlantic Web Intelligence Conference (pp. 240-249). Springer, Berlin, Heidelberg, 2003.

34. Zhu N, Zhang D, Wang W, Li X, Yang B et al. A novel coronavirus from patients with pneumonia in China, 2019. New England Journal of Medicine 2020.

35. Guan WJ, Ni ZY, Hu Y, Liang WH, Ou CQ et al. Clinical characteristics of coronavirus disease 2019 in China. New England Journal of Medicine (published online February 28, 2020). doi: 10.1056/ NEJMoa2002032

36. Chan JFW, Yuan S, Kok KH, To KKW, Chu H et al. A familial cluster of pneumonia associated with the 2019 novel coronavirus indicating person-to-person transmission: a study of a family cluster. The Lancet 2020; 395(10223): 514-523.

37. Wu Z, McGoogan JM. Characteristics of and important lessons from the coronavirus disease 2019 (COVID-19) outbreak in China: summary of a report of 72314 cases from the Chinese Center for Disease Control and Prevention. Jama 2020; 323(13): 1239-1242.

38. Zhou $P$, Yang $X L$, Wang $X G, H u$ B, Zhang $L$ et al. A pneumonia outbreak associated with a new coronavirus of probable bat origin. Nature 2020; 579(7798): 270-273.

39. Whipple ECE, Dixon B, McGowan J. Linking health information technology to patient safety and quality outcomes: A bibliometric analysis and review. Informatics for Health and Social Care 2013; 38(1): 1-14.

40. Tahamtan I, Bornmann L. What do citation counts measure? An updated review of studies on citations in scientific documents published between 2006 and 2018. Scientometrics 2019; 121(3): 1635-1684.

41. Milfont TL, Page E. A bibliometric review of the first thirty years of the journal of environmental psychology. Psyecology 2013; 4(2): 195-216.

42. Tran BX, Ha GH, Nguyen LH, Vu GT, Phan HT et al. Studies of Novel Coronavirus Disease 19 (COVID-19) Pandemic: A Global Analysis of Literature. medRxiv 2020.

43. Golinelli, D. , Nuzzolese, AG, Boetto, E., Rallo, F., Greco, M., Toscano, F., \& Fantini, MP (2020). The impact of early scientific literature in response to COVID-19: a scientometric perspective. medRxiv .

44. Chahrour M, Assi S, Bejjani M, Nasrallah AA, Salhab $H$ et al. A bibliometric analysis of Covid-19 research activity: A call for increased output. Cureus 2020; 12 (3).

45. Hossain MM. Current status of global research on novel coronavirus disease (Covid-19): A bibliometric analysis and knowledge mapping. Available at SSRN 2020; 3547824 .

46. Lou J, Tian SJ, Niu SM, Kang XQ, Lian HX et al. Coronavirus disease 2019: a bibliometric analysis and review. Eur Rev Med Pharmacol Sci 2020; 24(6): 3411-21.

47. Hamidah I, Sriyono S, Hudha MN. A Bibliometric Analysis of Covid-19 Research Using VOSviewer. Indonesian Journal of Science and Technology 2020; 5(2): 209-216. 
48. Nasab FR. Bibliometric analysis of global scientific research on SARSCoV-2 (COVID-19). medRxiv 2020.

49. Dehghanbanadaki $H$, Seif $F$, Vahidi $Y$, Razi $F$, Hashemi $E$ et al. Bibliometric analysis of global scientific research on Coronavirus (COVID-19). Medical Journal of The Islamic Republic of Iran (MJIRI) 2020; 34(1): 354-362.

50. Holshue ML, DeBolt C, Lindquist S, Lofy KH, Wiesman J et al. First case of 2019 novel coronavirus in the United States. New England Journal of Medicine 2020.

51. Lu R, Zhao X, Li J, Niu P, Yang B et al. Genomic characterization and epidemiology of 2019 novel coronavirus: implications for virus origins and receptor binding. The Lancet 2020; 395(10224): 565-574.

52. Wang $M$, Cao R, Zhang L, Yang $X$, Liu J et al. Remdesivir and chloroquine effectively inhibit the recently emerged novel coronavirus (2019-nCoV) in vitro. Cell Research 2020; 30 (3): 269271. doi: 10.1038/s41422-020-0282-0.

53. Tufan A, Güler AA, Matucci-cerınıc M. COVID-19, immune system response, hyperinflammation and repurposing antirheumatic drugs. Turkish Journal of Medical Sciences, 2020, 50.SI-1: 620-632. 